\title{
Absorptive capacity, efficiency effect and competitors' spillovers
}

\author{
Stéphane Lhuillery
}

Published online: 6 April 2011

(C) Springer-Verlag 2011

\begin{abstract}
Standard innovation surveys do not consider incoming spillovers for non-innovative firms. As a consequence, empirical works may overestimate the absorptive capacity effect, particularly among competitors. The Swiss innovation surveys presented here measure the importance of knowledge for both innovating and non-innovating firms. This original feature enables us to show that knowledge from rivals actually deters manufacturing firms from engaging in $R \& D$ activities. We therefore provide stronger evidence that the efficiency effect due to intra-industry spillovers is larger than that generally estimated by data from standard surveys. The R\&D based absorptive capacity is weaker than expected, and non-innovative firms as well as non-R\&D firms heavily rely on their rivals' knowledge to maintain their technological capacities.
\end{abstract}

Keywords R\&D • Intra-industry spillovers • Absorptive capacity • Innovation surveys

JEL C $81 \cdot \mathrm{O} 31$

\section{Introduction}

Ever since the seminal article by Arrow (1962), many theoretical models using a symmetric view of knowledge spillovers (e.g. Spence 1984) have shown that R\&D efforts decrease with knowledge spillovers. A symmetric view of

\footnotetext{
S. Lhuillery $(\varangle)$

MTEI-CEMI, College du Management de la Technologie, EPFL,

Ecole Polytechnique Federale de Lausanne, Switzerland,

Odyssea 1.18, Station 5, 1015 Lausanne, Switzerland

e-mail: stephane.lhuillery@epfl.ch
} 
spillovers is usually implemented where no technological hierarchy among firms is supposed: in this case, outgoing knowledge spillovers dissuade a firm from investing in $R \& D$ (disincentive effect), whereas incoming knowledge spillovers encourage firms to reduce their own production of knowledge by free-riding other firms (efficiency effect). When an asymmetric view of knowledge spillovers among competitors is adopted, "technological leaders have less to learn from others than followers do" (Eeckhout and Jovanovic 2002). An increase in knowledge spillovers from leaders to followers tends to have the usual discouraging effects on competing leaders, but also induces a decrease in followers' $R \& D$ investment when one-way outgoing spillovers from leaders to followers are high and spillovers among competing leaders are low (Vandekerckhove and De Bondt 2008). In such a framework, it is interesting to note that lagging firms can choose to be pure imitators (See also Nelson and Winter 1982).

The importance of disincentive effect and efficiency effect was seriously challenged by Cohen and Levinthal (1989), when they suggested that R\&D investment can be seen as a strategic complement instead of a strategic substitute for firms: the deterring effects arising from knowledge spillovers may be dominated by the $\mathrm{R} \& \mathrm{D}$ efforts required to build an absorptive capacity, consequently enabling firms to capture external knowledge (the absorptive capacity effect). This persuasive argument was also in line with certain econometric studies which reported that firms benefiting from external knowledge were the same ones investing most in R\&D (Jaffe 1986; Levin 1988). However, there is no empirical consensus as to whether technological spillovers actually lower or promote incentives to invest in R\&D (Cohen 1995). Particularly, the importance of absorptive capacity over the deterring effect for spillovers is still an open question, despite extensive works on the importance of the disincentive effect through the analysis of appropriation strategies. Despite the lack of empirical evidence regarding this issue, there is a widespread and persistent conviction that absorptive capacity effect is dominant while the deterring effect is not very important. In particular, many scholars are persuaded that absorptive capacity effects compensate the efficiency effect among competitors who invest more in R\&D despite the ease of learning.

The present paper proposes to focus on the lack of attention given to the efficiency effect in empirical literature based on innovation questionnaires. The fact that standard innovation questionnaires assess incoming knowledge only for "innovative" firms has important consequences for the ability to identify their effects on R\&D. Employing a sub-sample restricted to innovative firms, using censored regressors and the introduction of a selection equation are some of the techniques which have been proposed by scholars to correct this problem. We argue, however, that these solutions, implemented in order to cope with selectivity, not only fail to provide accurate identification of spillover parameters, but also fail to unveil the strength of the efficiency effect of incoming spillovers on innovative inputs. We contend that this deterring effect has been particularly underestimated in the case of competitors' incoming knowledge. 
In order to test this proposal, we use the Swiss innovation panel data (KOFETH Zürich), composed of 1,744 manufacturing firms over four periods (19931995, 1996-1998, 1999-2001, 2002-2003) or 2,653 firm-years, to measure not only the importance of incoming external knowledge for innovators (as many innovation surveys do) but also that for non-innovators. First, all data are implemented in order to evaluate the "real" impact of rivals' knowledge on R\&D decisions. We then assess the different solutions proposed by scholars, restricting our use of Swiss data to that which a standard CIS questionnaire would generally offer.

The remainder of the paper is organized as follows. Section 2 briefly surveys the empirical literature on the impact of incoming knowledge spillovers on R\&D. Section 3 describes the data collected and section 4 presents the econometric methodology. Results are presented in the next section. The final section deals with our conclusions.

\section{Empirical background}

One of the major research avenues in the economics of innovation focuses on increasing scholars' understanding of how incoming knowledge is absorbed by firms. The absorptive capacity argument is based on the investments that firms make in order to achieve learning. In this framework, spillovers may encourage R\&D: the absorptive capacity effect is indeed likely to compensate for the traditional deterring effects of spillovers, which in turn are likely to remain dominant for "easy to learn" knowledge (Cohen and Levinthal 1989). This theoretical argument has been so successful that many scholars have been and continue to be persuaded that the absorptive capacity effect is always dominant, forgetting its possible weakness, especially in terms of suppliers' or competitors' incoming knowledge (Cohen and Levinthal 1989). In this respect, this persistent belief is supported by robust theoretical results focused on competitors (See Leahy and Neary 2007), and also by an extensive econometric literature on the role of intra-industry spillovers which is, however, not able to identify clearly the balance between the efficiency effect and the absorptive capacity effect. We propose to illustrate the difficulties by surveying the three different empirical methods implemented to identify the deterring effect of competitors' incoming knowledge on $\mathrm{R} \& \mathrm{D}$.

In a first method, scholars try to identify, directly through questionnaires, those firms which are imitators or laggards. The asymmetric view of spillovers employs the idea that laggards benefit more from leaders and thus need to invest less in R\&D. Using this concept, Link and Neufeld (1986) confirmed that imitators are less R\&D intensive than innovators.

The second method does not introduce any differences between firms, considering that each firm supplies all its rivals with knowledge through outgoing spillovers and that the latter supply the former in a reciprocal fashion. In this framework, an external pool of knowledge is computed, in order to assess if there is a negative impact of the potential incoming knowledge 
spillovers on R\&D investment. Bernstein and Nadiri (1989) found a deterring effect. The robustness of this result has, however, been challenged by several papers: Bloom et al. (2007) suggest, for example, that the disincentive effect of competitors' R\&D is not robust when strategic externalities are controlled for. Jaffe (1986) reports that the R\&D pool positively affects the number of patents filed, but also that $R \& D$ intensity and the intra-industry R\&D pool are complementary.

The third method stems from the emergence in the 1980s of a qualitative and direct measurement of the role of incoming knowledge in the innovation process (see Levin et al. 1987; OECD 1992). Adopted by different innovation surveys ${ }^{1}$ ever since 1992, in this approach, the question asked respecting incoming knowledge may be, for example, "Please indicate the sources of knowledge or information used in your technological innovation activities, and their importance during the period 1998-2000" (from UK CIS3), where answers are given for each type of external source (parent firms, customers, suppliers, competitors, universities, consultants) and are ranked according to their degree of importance (Not used, Low, Medium, High). In these standardized CIS questionnaires, incoming spillover variables are observed only for the sub-set of innovative firms. Yet, incoming knowledge is also important for non-innovating firms in order to maintain their technological capacities. Technological capacities of non-innovative firms may be not high enough to generate genuine innovation or significant improvements in processes or products, but are still very important in maintaining high performance within a firm which uses almost the same processes and products (learning curves) or which may want to keep open the opportunity to innovate in the future (option value; Kogut and Kulatilaka 2001).

A selection problem, therefore, exists in the direct measurement of incoming spillovers, and two different solutions to this question can be found in the academic literature. The first, which is also the most popular among scholars, proposes reducing the analysis to the sub-sample of innovative firms. In this setting, Cassiman and Veugelers (2006) show on a restricted sample of Belgium firms that rivals' ideas induce firms to invest less in R\&D, subcontract it to a greater extent, or buy it outright. Obtained from a US sample of firms in which R\&D performers prevail, Cohen and Levinthal (1989) further suggest that the absorptive capacity effect is dominant only in a few high-tech industries (chemicals and electrical equipment).

The second solution, initiated by Crépon et al. (1998), analyzes R\&D decisions on the whole sample of firms, including non-innovators. In this case, variables on incoming knowledge need to be censored in order to be introduced in R\&D equations (Lööf and Heshmati 2002; Griffith et al. 2006; Raffo et al. 2008). The different authors assume that non-innovating firms do not benefit from external sources of technological knowledge and, consequently,

\footnotetext{
${ }^{1}$ Community innovation surveys and also numerous innovation surveys carried out in developing countries based sometime on the "Bogota Manual" (See Raffo et al. 2008 for main references).
} 
incoming knowledge is forced to the minimum value of the Likert scale (i.e. it is not important). Along these lines, regarding the $R \& D$ intensity equation, Raffo et al. (2008) do not find any significant effect of rivals' knowledge for Swiss firms, but instead report a positive one for French firms, suggesting a dominant absorption capacity effect over the efficiency effect. ${ }^{2}$

The two solutions are laudable efforts to overcome the selectivity problem regarding incoming knowledge variables. We contend, however, that they do not provide accurate identification of the role of rivals' ideas in terms of innovation inputs. The decision to invest in $\mathrm{R} \& \mathrm{D}$ is influenced by incoming spillovers influencing all firms, including non-innovative ones. To restrict the analysis to innovative firms is to neglect potential selection biases. The introduction of a selection equation may not properly correct for these biases, since incoming knowledge certainly influences also the selection process. The use of censored regressors, as carried out by Griffith et al. (2006), is an interesting solution, but may induce upward biases (Rigobon and Stoker 2007). These biases are likely to be more important both for incoming knowledge, which is easy to learn for non-innovative firms-namely competitors' knowledge spillovers-and also, to some extent, for suppliers' knowledge, which is often embodied in capital goods.

The next sections assess the role of incoming spillovers, especially from competitors, on R\&D decisions by implementing uncensored data. First, the real impact of incoming spillovers is evaluated. The results from this are then used as a benchmark in order to compare the results that would be obtained with data coming from a standard innovation questionnaire.

\section{Data and variables}

The data used in this study comes from the 1996, 1999, 2002 and 2005 Swiss innovation surveys administrated by the KOF. The four waves of the Swiss questionnaire are similar to the Community Innovation Survey (CIS) questionnaire examining the nature and impact of innovation in the business sector at the European Union level and draw extensively on the Oslo manual's guidelines (OECD 1992). The data include measures of innovation-related expenditure, factors which have either encouraged or hampered innovation, including property rights, and the innovation outcome.

As already suggested, the KOF questionnaires $(1996,1998,2002,2005)$ depart from other standard innovation questionnaires (e.g. from CIS1 to CIS4), exploring the source of external technological information and knowledge for innovative and non-innovative firms. The Swiss questionnaire uses the same method to measure directly incoming knowledge, but is more general, asking the question "What is the importance of external sources of knowledge

\footnotetext{
${ }^{2}$ The external sources were successfully introduced into the R\&D intensity equation by Griffith et al. (2006), but the coefficients were not reported by the authors.
} 
Table 1 Description of variables

\begin{tabular}{|c|c|}
\hline Variable name & Definition \\
\hline \multicolumn{2}{|l|}{ Dependent variables } \\
\hline$R \& D Y E S$ & $\begin{array}{l}\text { Dummy variable which takes the value } 1 \text { if the enterprise reports } \\
\text { engagement in intramural } R \& D \text { and a positive } R \& D \text { budget. }\end{array}$ \\
\hline $\mathrm{R} \& \mathrm{DI}^{\mathrm{a}}$ & $\begin{array}{l}\text { Research and development investment / sales for the last year of } \\
\text { the three year period (plus the minimum of the positive value } \\
\text { of the ratio and then taken in logarithm) }\end{array}$ \\
\hline \multicolumn{2}{|l|}{ Explanatory variables } \\
\hline PARENT & $\begin{array}{l}\text { Dummy variable which takes the value } 1 \text { if knowledge from } \\
\text { parent firms was important or of great importance during } \\
\text { the three year period }\end{array}$ \\
\hline CUSTOMER & $\begin{array}{l}\text { Dummy variable which takes the value } 1 \text { if knowledge from } \\
\text { customers or clients was important or of great importance } \\
\text { during the three year period }\end{array}$ \\
\hline COMPETITOR & $\begin{array}{l}\text { Dummy variable which takes the value } 1 \text { if knowledge from } \\
\text { competitors and other firms from the same industry was } \\
\text { important or of great importance during the three year period }\end{array}$ \\
\hline SUPPLIER & $\begin{array}{l}\text { Dummy variable which takes the value } 1 \text { if knowledge from } \\
\text { suppliers was important or of great importance during } \\
\text { the three year period }\end{array}$ \\
\hline UNIVERSITY & $\begin{array}{l}\text { Dummy variable which takes the value } 1 \text { if knowledge from } \\
\text { universities or colleges was important or of great importance } \\
\text { during the three year period }\end{array}$ \\
\hline CONSULTANT & $\begin{array}{l}\text { Dummy variable which takes the value } 1 \text { if knowledge from } \\
\text { consultancy firms or technological transfer firms was important } \\
\text { or of great importance during the three year period }\end{array}$ \\
\hline $\mathrm{R} \& \mathrm{D} \mathrm{COOP}^{\mathrm{a}}$ & $\begin{array}{l}\text { Dummy variable which takes the value } 1 \text { if the firm had some } \\
\text { cooperative arrangements for their } R \& D \text { activities during } \\
\text { the three year period }\end{array}$ \\
\hline APPROPRIATION & $\begin{array}{l}\text { Dummy variable which takes the value } 1 \text { when the competitive } \\
\text { advantages due to product or process innovations are declared } \\
\text { to protected in to a large of very large extent by IPR or non-IPR } \\
\text { strategies (e.g. patents, trademarks trade, copyright, secrecy, } \\
\text { advantage time, product or process complexity, long-term } \\
\text { employment of specialized personnel, etc.) during the } \\
\text { three year period. }\end{array}$ \\
\hline Size & $\begin{array}{l}\text { Logarithm of the number of employees for the last year of the } \\
\text { three year period. }\end{array}$ \\
\hline Price competition $^{b}$ & $\begin{array}{l}\text { Dummy variable which takes the value } 1 \text { when the intensity } \\
\text { of price competition is considered to be strong or very strong. }\end{array}$ \\
\hline Non Price competition ${ }^{b}$ & $\begin{array}{l}\text { Dummy variable which takes the value } 1 \text { when the intensity of } \\
\text { non-price competition is considered to be strong or very strong. }\end{array}$ \\
\hline $\begin{array}{l}\text { Perceived number } \\
11 \text { to } 15 \text { of competitors }{ }^{b}\end{array}$ & $\begin{array}{l}\text { Dummies for four different market types: more than } 50 \\
\text { competitors in the (worldwide) product market; } 16 \text { to } 50 \\
\text { competitors; competitors; } 6 \text { to } 10 \text { competitors; (reference } \\
\text { group: up to } 5 \text { competitors) }\end{array}$ \\
\hline
\end{tabular}

external to your firm for your own capacity of innovation" and rating the replies on a five-point Likert scale. Non-innovating firms are thus asked to answer the question following the assumption that such firms have, in fact, their own "capacity of innovation", something which is not taken into account in standard questionnaires. 
Table 1 (continued)

\begin{tabular}{ll}
\hline Variable name & Definition \\
\hline Demand $^{\mathrm{b}}$ & $\begin{array}{c}\text { Dummy variable which takes the value } 1 \text { when the technological } \\
\text { potential of the firm's industry is considered to be strong or }\end{array}$ \\
& very strong over the next three years. \\
Technology potential $^{\mathrm{b}}$ & $\begin{array}{c}\text { Dummy variable which takes the value } 1 \text { when the demand } \\
\text { development expectations for the main market are considered } \\
\text { to be strong or very strong. } \\
\text { INDUS }\end{array}$ \\
& Set of 14 industry dummies according to the firm's main business \\
& activity (2 digit level of NACE) \\
\hline
\end{tabular}

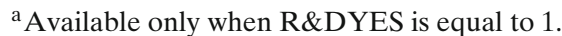

${ }^{b}$ These variables arise from direct questions which are specific to the Swiss questionnaire and which are usually not included in standard CIS questionnaires.

Beyond the incoming knowledge per type of external source (BUSINESS GROUP, SUPPLIER, COMPETITOR, CUSTOMER, UNIVERSITY, CONSULTANT), the other variables available are very similar to those of the CIS, as reported in Table 1. The Swiss innovation panel data covers innovation inputs (R\&DYES, R\&DI, R\&D COOP) and efficiency of appropriation strategies (APPROPRIATION). As Table 1 also reports, the Swiss questionnaire includes general questions providing usual control variables (size, industry), as well as Swiss specific questions providing additional control variables (price and non-price competition, perceived number of competitors, technology potential and demand anticipated).

The Swiss innovation panel is a collection of four innovation surveys among Swiss firms for the years 1996, 1999, 2002 and 2005. These surveys were based on stratified random samples of firms with at least five employees, covering all manufacturing industries and some services (see Arvanitis 2008). The KOF survey is a voluntary mail survey with response rates for the covered manufacturing firms as follows: $33.5 \%$ (1996), 33.7\% (1999), 44.6\% (2002) and 38.7\% (2005). Our final data, restricted to the manufacturing industry, omitting all firm-years with missing values, firms with fewer than five employees, and firms with more than $50 \%$ of their activity spent in $R \& D$, is an unbalanced panel of 2,653 firm-years $(680,633,890,450$ for the years 1996, 1999, 2002, 2005, respectively) for 1,744 firms distributed over the four periods, and may be considered as representative of the Swiss manufacturing industry. ${ }^{3}$

We now propose an empirical model which will serve as a guideline to compare the results obtained with two of the different possible solutions proposed in the literature and outlined above.

\footnotetext{
${ }^{3}$ In line with the literature, we consider that firms with more than $50 \%$ of sales should have been filed into the R\&D service class (NACE 731). We thus do not consider these firms, since we restrict ourselves to manufacturing industries. In the paper, we do not use imputed values for the different variables, so the number of firm-years available is thus reduced. The final sample is unbalanced: out of the 1,744 firms, 1082 were present during one period, 453 during two periods, 165 during three periods, and only 41 during all four periods.
} 


\section{Econometric modeling}

In order to evaluate the differences between the usual solutions and those facilitated by the Swiss data, we propose a Heckman model explaining the decision to commit to $\mathrm{R} \& \mathrm{D}$ activities and the decision regarding R\&D intensity. Our model departs from the canonical R\&D model (Cohen and Levinthal 1989; Crépon et al. 1998; Griffith et al. 2006; Raffo et al. 2008) in two ways. First, we focus on competitor incoming spillovers, since the efficiency effect is expected to be the largest and the potential upward biases the most important for this variable compared with the other incoming spillovers variables. Second, this paper proposes an extension of the usual cross-sectional model into four period panel data (1993-1995, 1996-1998, 1999-2001, 2002-2004). This extension is, however, difficult for the first equation exploring the likelihood of being R\&D active, since two thirds of firms are stable R\&D investors or non $R \& D$ investors and so the interest in using a panel probit model with fixed effects (FE hereafter) is greatly reduced. Instead, we propose estimating a sample selection model with random effects (RE) as follows: ${ }^{4}$

$$
\left\{\begin{array}{l}
R \& D Y E S_{i t}^{*}=\underset{<0}{\kappa_{1}^{\prime} C O M P E T I T O R}+\chi_{1}^{\prime} s_{1 i t}+\delta^{\prime} \mathrm{w}_{\mathrm{it}}+u_{1 \mathrm{i}}+\varepsilon_{1 \mathrm{it}} \\
R \& D I_{i t}^{*}=\underset{<0}{\kappa_{2}^{\prime} C O M P E T I T O R}+\chi_{2}^{\prime} s_{2 i t}+\beta^{\prime} \mathrm{x}_{\mathrm{it}}+u_{2 \mathrm{i}}+\varepsilon_{2 \mathrm{it}}
\end{array}\right.
$$

where $R \& D Y E S$ is the observed binary variable, equal to 0 for non-R\&D firms and 1 for firms reporting some positive internal $R \& D$, and where a negative coefficient is expected for the COMPETITOR variable $\left(\kappa_{1}<0\right.$ in subscript) in which we are especially interested, whereas $\mathbf{s}$ is the matrix for other external sources of knowledge. $\mathbf{w}$ is a matrix for other variables including APPROPRIATION, where a positive sign is expected. ${ }^{5}$ APPROPRIATION controls for the ability of firms to control outgoing spillovers and the impact of the disincentive effect on $\mathrm{R} \& \mathrm{D}$. Other variables are control variables such as size, perceived number of competitors, type of competition, technological potential and anticipated demand explaining R\&D decisions. $\chi_{1}$ and $\delta$ are vectors of parameters of interest to be estimated. $\mathbf{u}_{1}$ a firm specific random term and $\varepsilon_{1}$ an error term.

Conditional on firm $\mathbf{i}$ reporting systematic $\mathrm{R} \& \mathrm{D}$, the declared intensity R\&DI of the latent variable R\&DI* is then observed and explained when

\footnotetext{
${ }^{4}$ Note that a Simple Tobit model can be implemented in place of the Heckman model. The use of a fixed effect Tobit model for panel data is, however, a problem in our case because of the restricted number of periods (See Greene 2006). The simple Tobit results on R\&DI with RE or even FE, that are consistent with our results obtained with the RE Heckman model, are available upon request.

${ }^{5}$ The PUBLIC FUNDING variable has been included in KOF questionnaires only since the 1999 version. In order to keep our four periods instead of only three, we do not introduce the variable that is endogenous and, in any case, concerns very few companies in Switzerland.
} 
R\&DYES is 1 . In the R\&D intensity equation, if the efficiency effect prevails over the absorptive capacity effect, the coefficient of COMPETITOR is also expected to be negative $\left(\kappa_{2}<0\right)$. $\mathbf{s}_{2}$ and $\mathbf{x}$ are matrixes of variables explaining R\&D intensity. $\mathbf{s}_{2}$ is defined as above; compared with $\mathbf{w}$, the $\mathbf{x}$ matrix includes an additional variable, an R\&D cooperation dummy ( $\&$ D COOP). The introduction of this latter is carried out in order to control for the different roles played by internalized and non-internalized incoming spillovers (See Belderbos et al. 2004; Leahy and Neary 2007). The variable is, however, not observed for non-innovative firms (see Lhuillery and Pfister 2009 for related discussion on this problem) and therefore cannot be introduced into Eq. 1. $\chi_{2}$ and $\boldsymbol{\beta}$ are vectors of parameters of interest to be estimated. $\mathbf{u}_{2}$ is a firm specific random term and $\varepsilon_{\mathrm{y}}$ an error term. The same four periods are considered.

Using this framework, we first present the "true" model for all Swiss firms, both innovative and non-innovative, which use incoming knowledge spillovers. Using Griffith et al.'s (2006) interesting idea, a second set of specifications is then proposed to introduce censored regressors, considering that external knowledge is not important to non-innovative firms. In a formal way, the COMPETITOR $_{\mathrm{it}}^{\text {censored }}$ variable is, as for the other external source variables,

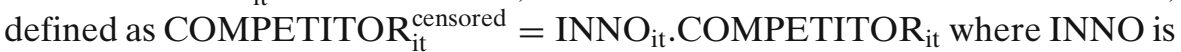
a dummy set to 0 when the firm declares itself as non-innovative. The censored variables are thus introduced in place of uncensored variables in Eq. 2. Finally, a third set of regressions implements Eqs. 1 and 2 specifically for innovative firms only.

\section{Results}

Descriptive statistics are reported in Table 2. In our sample, around $78 \%$ of firm-years are innovative and $58 \%$ of these declare some kind of positive R\&D profile. In addition, $26 \%$ of innovative firms cooperate with other firms in R\&D. Unsurprisingly, non-innovative firms are smaller than innovative ones and these perceive fewer competitors than the former. They also declare more often that they compete on a non-price basis ( $46 \%$ vs $27 \%$ ). More interesting is the importance of incoming spillovers for non-innovative firms which benefit to a great extent from external knowledge but in a less systematic way, especially in terms of knowledge coming from parent firms, clients, universities, or consultants. Non-innovating firms depend more on their competitors $(41 \%)$ or suppliers $(29 \%)$ to maintain their technological capacities than innovative firms (33\% and $22 \%$ respectively) or even firms carrying out R\&D ( $34 \%$ and $21 \%$ respectively).

As Table 3 reports, the level of $R \& D$ investment is not significantly influenced by external knowledge: firms increase their R\&D investment in order to capture academic knowledge and decrease such investment when they benefit from their own business group knowledge. The important role of competitors is unveiled when rivals' knowledge is introduced into Eq. 1. As column [1a] reveals, when a firm benefits from its rivals' knowledge, the 


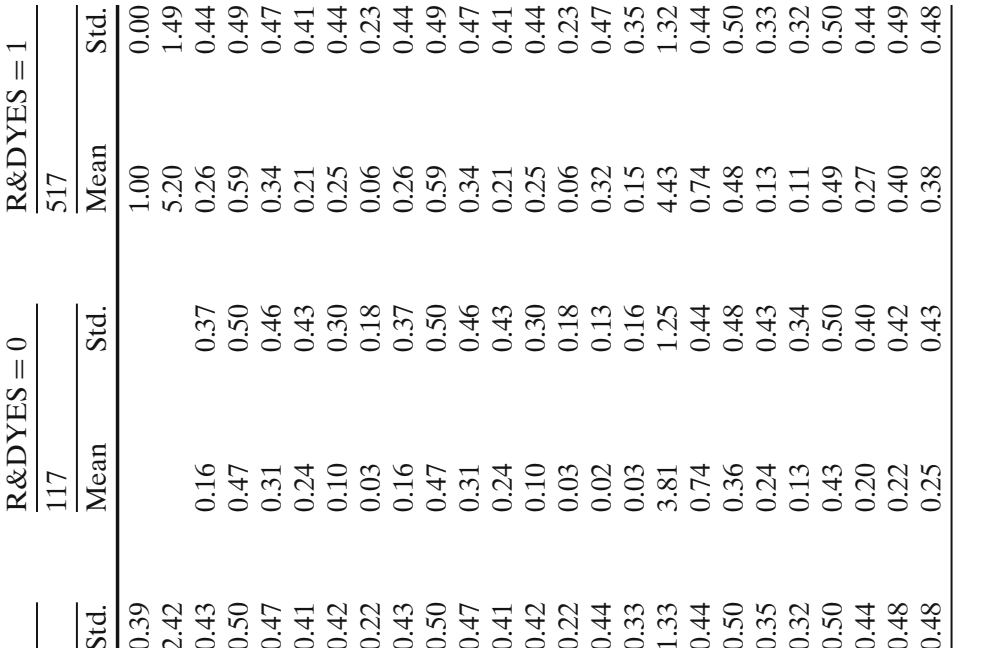

Ð) 5

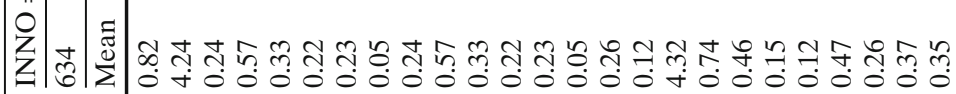


Table 3 Innovation inputs

\begin{tabular}{|c|c|c|c|c|c|c|}
\hline $\begin{array}{l}\text { Column [Equation-model] } \\
\text { Model }\end{array}$ & $\begin{array}{l}{[1 \mathrm{a}]} \\
\text { Heckman }\end{array}$ & {$[2 \mathrm{a}]$} & $\begin{array}{l}{[1 \mathrm{~b}]} \\
\text { Heckman }\end{array}$ & {$[2 \mathrm{~b}]$} & $\begin{array}{l}{[1 \mathrm{c}]} \\
\text { Heckman }\end{array}$ & {$[2 \mathrm{c}]$} \\
\hline Firms & All & & All & & $\mathrm{INNO}=1$ & \\
\hline Ext. source regre & $\overline{\text { Uncensored }}$ & $\overline{\text { sored }}$ & $\overline{\mathrm{No}}$ & $\overline{\text { sored }}$ & Uncensored & $\overline{\text { sored }}$ \\
\hline Explained Variable & R\&DYES & $\mathrm{R} \& \mathrm{DI}$ & R\&DYES & $\mathrm{R} \& \mathrm{DI}$ & R\&DYES & R\&DI \\
\hline Competitors $^{\mathrm{a}}$ & $\begin{array}{l}-0.257 * * * \\
(0.073)\end{array}$ & $\begin{array}{l}-0.001 \\
(0.060)\end{array}$ & & $\begin{array}{c}-0.013 \\
(0.060)\end{array}$ & $\begin{array}{l}0.048 \\
(0.098)\end{array}$ & $\begin{array}{l}-0.005 \\
(0.062)\end{array}$ \\
\hline Clients $^{\mathrm{a}}$ & $\begin{array}{l}0.183 \text { *** } \\
(0.068)\end{array}$ & $\begin{array}{l}0.102 * \\
(0.059)\end{array}$ & & $\begin{array}{l}0.107 * \\
(0.058)\end{array}$ & $\begin{array}{l}0.016 \\
(0.092)\end{array}$ & $\begin{array}{l}0.096 \\
(0.061)\end{array}$ \\
\hline Suppliers ${ }^{\mathrm{a}}$ & $\begin{array}{l}-0.137^{*} \\
(0.080)\end{array}$ & $\begin{array}{l}-0.053 \\
(0.066)\end{array}$ & & $\begin{array}{l}-0.053 \\
(0.066)\end{array}$ & $\begin{array}{l}-0.062 \\
(0.108)\end{array}$ & $\begin{array}{l}-0.098 \\
(0.070)\end{array}$ \\
\hline Universities and Colleges ${ }^{a}$ & $\begin{array}{l}0.278^{* * * *} \\
(0.093)\end{array}$ & $\begin{array}{l}0.248 * * * \\
(0.066)\end{array}$ & & $\begin{array}{l}0.277 * * * \\
(0.066)\end{array}$ & $\begin{array}{l}0.425^{* * * *} \\
(0.136)\end{array}$ & $\begin{array}{l}0.254 * * * \\
(0.072)\end{array}$ \\
\hline Consultants ${ }^{\mathrm{a}}$ & $\begin{array}{l}-0.047 \\
(0.140)\end{array}$ & $\begin{array}{l}-0.055 \\
(0.099)\end{array}$ & & $\begin{array}{l}-0.041 \\
(0.099)\end{array}$ & $\begin{array}{l}0.113 \\
(0.195)\end{array}$ & $\begin{array}{l}-0.026 \\
(0.103)\end{array}$ \\
\hline Business group $^{a}$ & $\begin{array}{l}0.025 \\
(0.086)\end{array}$ & $\begin{array}{l}-0.135^{* *} \\
(0.064)\end{array}$ & & $\begin{array}{l}-0.139 * * \\
(0.065)\end{array}$ & $\begin{array}{l}0.084 \\
(0.117)\end{array}$ & $\begin{array}{l}-0.125^{*} \\
(0.067)\end{array}$ \\
\hline $\mathrm{R} \& \mathrm{D}$ cooperation ${ }^{\mathrm{a}}$ & & $\begin{array}{l}0.214 * * * * \\
(0.056)\end{array}$ & & $\begin{array}{l}0.215 * * * \\
(0.056)\end{array}$ & & $\begin{array}{l}0.226 * * * \\
(0.058)\end{array}$ \\
\hline Appropriation efficiency ${ }^{\mathrm{a}}$ & $\begin{array}{l}0.328 * * * \\
(0.101)\end{array}$ & $\begin{array}{l}0.078 \\
(0.071)\end{array}$ & $\begin{array}{l}0.319 * * * \\
(0.097)\end{array}$ & $\begin{array}{l}0.073 \\
(0.071)\end{array}$ & $\begin{array}{l}0.540 * * * \\
(0.142)\end{array}$ & $\begin{array}{l}0.092 \\
(0.075)\end{array}$ \\
\hline Size & $\begin{array}{l}0.418 \text { *** } \\
(0.029)\end{array}$ & $\begin{array}{l}-0.501 * * * * \\
(0.097)\end{array}$ & $\begin{array}{l}0.413 * * * \\
(0.028)\end{array}$ & $\begin{array}{l}-0.501 * * * \\
(0.096)\end{array}$ & $\begin{array}{l}0.222 \text { *** } \\
(0.036)\end{array}$ & $\begin{array}{l}-0.447 \text { **** } \\
(0.101)\end{array}$ \\
\hline Size squared & & $\begin{array}{l}0.047 * * * \\
(0.010)\end{array}$ & & $\begin{array}{l}0.046^{* * * *} \\
(0.010)\end{array}$ & & $\begin{array}{l}0.042 * * * \\
(0.010)\end{array}$ \\
\hline Price competition $^{\mathrm{a}}$ & $\begin{array}{l}0.025 \\
(0.081)\end{array}$ & $\begin{array}{l}-0.023 \\
(0.064)\end{array}$ & $\begin{array}{l}0.016 \\
(0.079)\end{array}$ & $\begin{array}{l}-0.023 \\
(0.065)\end{array}$ & $\begin{array}{l}-0.021 \\
(0.106)\end{array}$ & $\begin{array}{l}-0.039 \\
(0.066)\end{array}$ \\
\hline Non-price competition ${ }^{\mathrm{a}}$ & $\begin{array}{l}0.220 * * * \\
(0.070)\end{array}$ & $\begin{array}{l}0.022 \\
(0.056)\end{array}$ & $\begin{array}{l}0.215^{* * * *} \\
(0.069)\end{array}$ & $\begin{array}{l}0.011 \\
(0.056)\end{array}$ & $\begin{array}{l}0.087 \\
(0.092)\end{array}$ & $\begin{array}{l}0.032 \\
(0.059)\end{array}$ \\
\hline No. of competitors (16 to 50$)^{\mathrm{a}}$ & $\begin{array}{l}-0.132 \\
(0.123)\end{array}$ & $\begin{array}{l}0.191 * * \\
(0.097)\end{array}$ & $\begin{array}{l}-0.136 \\
(0.121)\end{array}$ & $\begin{array}{l}0.214 * * \\
(0.097)\end{array}$ & $\begin{array}{l}-0.074 \\
(0.152)\end{array}$ & $\begin{array}{l}0.206 * * \\
(0.104)\end{array}$ \\
\hline No. of competitors (11 to 15$)^{\mathrm{a}}$ & $\begin{array}{l}0.050 \\
(0.088)\end{array}$ & $\begin{array}{l}0.136 \text { *** } \\
(0.071)\end{array}$ & $\begin{array}{l}0.054 \\
(0.086)\end{array}$ & $\begin{array}{l}0.147 * * \\
(0.071)\end{array}$ & $\begin{array}{l}0.094 \\
(0.109)\end{array}$ & $\begin{array}{l}0.155^{* *} \\
(0.075)\end{array}$ \\
\hline No. of competitors $(1 \text { to } 10)^{\mathrm{a}}$ & $\begin{array}{l}0.118 \\
(0.109)\end{array}$ & $\begin{array}{l}0.221 * * * \\
(0.084)\end{array}$ & $\begin{array}{l}0.129 \\
(0.106)\end{array}$ & $\begin{array}{l}0.226^{* * * *} \\
(0.084)\end{array}$ & $\begin{array}{l}0.284 * * \\
(0.142)\end{array}$ & $\begin{array}{l}0.238 * * * \\
(0.088)\end{array}$ \\
\hline Techno. Potential ${ }^{\mathrm{a}}$ & $\begin{array}{l}0.469 * * * \\
(0.078)\end{array}$ & $\begin{array}{l}0.128^{* *} \\
(0.059)\end{array}$ & $\begin{array}{l}0.482 * * * \\
(0.075)\end{array}$ & $\begin{array}{l}0.127 * * \\
(0.060)\end{array}$ & $\begin{array}{l}0.230 * * \\
(0.101)\end{array}$ & $\begin{array}{l}0.138 * * \\
(0.063)\end{array}$ \\
\hline Demand $^{\mathrm{a}}$ & $\begin{array}{l}0.423 \text { *** } \\
(0.073)\end{array}$ & $\begin{array}{l}0.134^{* *} \\
(0.058)\end{array}$ & $\begin{array}{l}0.421 * * * \\
(0.072)\end{array}$ & $\begin{array}{l}0.135^{* *} \\
(0.058)\end{array}$ & $\begin{array}{l}0.256^{* * * *} \\
(0.094)\end{array}$ & $\begin{array}{l}0.145 * * \\
(0.060)\end{array}$ \\
\hline Industry dummies & Yes & Yes & Yes & Yes & Yes & Yes \\
\hline Log-Likelihood & \multicolumn{2}{|c|}{-4378.4} & \multicolumn{2}{|c|}{-4389.5} & \multicolumn{2}{|c|}{-3762.2} \\
\hline Firm-Years & \multicolumn{2}{|c|}{2653} & \multicolumn{2}{|c|}{2653} & \multicolumn{2}{|c|}{2103} \\
\hline Uncensored Firm-Years & \multicolumn{2}{|c|}{1826} & \multicolumn{2}{|c|}{1826} & \multicolumn{2}{|c|}{1826} \\
\hline Firms & \multicolumn{2}{|c|}{1744} & \multicolumn{2}{|c|}{1744} & \multicolumn{2}{|c|}{1420} \\
\hline
\end{tabular}

The periods considered are 1993-1995, 1996-1998, 1999-2001 and 2002-2004. All models are random effects. Marginal effects and industry dummies are not reported. Size squared was not significant when introduced into the R\&DYES equation. Without any change in the other results, this variable is excluded in the final specification (i.e. in $1 \mathrm{a}, 1 \mathrm{~b}$ and $1 \mathrm{c}$ ).

$* p=0.1, * * p=0.05, * * * p=0.01$

${ }^{\text {a }}$ Dummy variable

likelihood of it investing in R\&D diminishes. This result is new, as the existing literature usually introduces external knowledge only in the R\&D intensity equation (see [1b]) or limits the investigation to innovative firms (see [1c]). The impact of competitors' knowledge on R\&D intensity is still not significant (compare [2a], [2b] and [2c]) underlying the difference between firms with and without R\&D. 
A similar conclusion is reached for knowledge coming from suppliers: the efficiency effect is in fact much stronger than a CIS based study would suggest. The result is in line with the idea that knowledge embodied in capital goods is less costly to adopt and requires less absorptive capacities than more disembodied incoming knowledge (Cohen and Levinthal 1989). Our results also confirm the positive role of customers' knowledge on R\&D decisions (Column [1a] or column [2a]). Similarly, the existence of a dominant absorptive capacity effect is preserved with respect to the role of universities as sources of knowledge (Column [1a] to [2c]).

The results confirm that standard studies based on direct measure of incoming knowledge understate the importance of the efficiency effect of intrasectoral spillovers on R\&D. Disregarding the fact that rivals' ideas provide the opportunity to NOT invest in $\mathrm{R} \& \mathrm{D}$, scholars overestimate the absorptive capacity effect that is not found dominant for firms investing in R\&D. The different results support our hypothesis that questionnaires focusing solely on innovative firms induce significant difficulties for scholars when trying to identify the real effect of spillovers.

The present paper also confirms some other hypotheses usually found in the literature. For instance, R\&D co-operation is found to influence positively R\&D intensity [2a]. Large firms are more likely to be involved in $R \& D$ activities [1a] or to be R\&D intensive [1b] ${ }^{6}$ than SMEs.

Appropriation is found to be, as expected, positively related to the decision to invest in R\&D (See Table 3, [1a]). However this positive effect vanishes for $R \& D$ intensity ([2a]). One interpretation for this is that many non-innovators are laggards for whom it is easier to efficiently protect their know-how. These firms subsequently declare that they are able to protect their advantage, whereas the same task is considered to be more difficult by innovators and especially technological leaders. However, appropriation is likely to be endogenous in this model-firms may implement appropriation strategies when they obtain outcomes from R\&D activities. Consequently, we do not elaborate further on this result, since the identification of coefficients can be fragile.

The perceived number of competitors is found to deter firms from being R\&D intensive ([2a]). This result is in line with the traditional idea that firms that monopolize power within their market niche are more likely to get returns from their R\&D investments.

\section{Conclusion}

The Swiss innovation questionnaires include an original measurement of the impact of incoming knowledge on a firm's innovation capacities: the measure

\footnotetext{
${ }^{6}$ The $\mathrm{U}$ shaped curve reaches a minimum for 150 employees.
} 
is performed on innovating and non-innovative firms. The resulting data facilitates the identification of the "true" impact of incoming knowledge and especially of competitors' ideas on $\mathrm{R} \& \mathrm{D}$ decisions. It also enables us to compare these results with those usually produced with a standard innovation questionnaire. In this respect, we argue that the standard innovation questionnaire focusing on innovative firms introduces a systematic upward bias when the impact of external knowledge on $\mathrm{R} \& \mathrm{D}$ is considered. More specifically, we argue that studies, based on CIS questionnaires or based only on firms with innovation activities, fail to show the importance of the efficiency effect (firms reduce their own production of knowledge by freeriding other firms) regarding the decision to invest in $\mathrm{R} \& \mathrm{D}$. The empirical results confirm our hypothesis. Unlike results that can be obtained using a common CIS questionnaire, rivals' spillovers dissuade firms from engaging in R\&D activities. These results contradict the general belief that the efficiency effect due to incoming spillovers is usually dominated by counterbalancing absorptive capacity effects large enough to create strategic complementarities among competitors.

Our results do not imply that the absorption theory does not hold anymore. Even if we do not find a positive link between R\&D intensity and competitors' spillovers, our results suggest that the standard absorptive capacity effect is more important for those firms carrying out $\mathrm{R} \& \mathrm{D}$ or which are technological leaders. These same firms disclose knowledge thereby dissuading R\&D investment for non-R\&D investors and technological laggards. At the same time, many lagging firms are unlikely to get positive returns from R\&D investments and are more likely to survive relying on external sources such as competitors or suppliers.

These empirical results rejuvenate the idea that intra-industry spillovers act as a critical determinant of technological strategies. They also support theoretical considerations which insist on the importance of active imitation strategies among learning competitors with asymmetric spillovers (Nelson and Winter 1982; Eeckhout and Jovanovic 2002; Ceccagnoli 2005; Vandekerckhove and De Bondt 2008) where laggards, non innovators or firms without R\&D, learn from other firms, especially from competitors closer to cutting-edge technological development.

The present paper underlines the limitations of the CIS questionnaire and illustrates, through the KOF questionnaire, their possible extension toward noninnovators on questions pertaining to knowledge sourcing. The differences found between $R \& D$ active and non-active firms also argue for a direct measurement of technology positions among competitive firms. Questionnaires could first try to tackle this difficult issue through a characterization of the imitation strategies used by firms. Our opinion is that the usual question asked in innovation questionnaires, distinguishing between an innovation "new to the firm" but "not new to the market", may identify followers but fail to identify imitators. Certain firms can consider themselves as non-innovating because they do not judge their imitation strategy as an innovative strategy. The two changes in questionnaires would facilitate the testing of theoretical 
models with asymmetric spillovers more precisely and would alleviate a major impediment in the understanding of patterns of industrial evolution.

Finally, the present paper does not explain how non-innovative firms or non-R\&D firms are able to capture external knowledge. The hypothesis that $\mathrm{R} \& \mathrm{D}$ is a latent variable is an appealing but oversimplified explanation. The content and role of a non-R\&D based absorptive capacity are an open question.

Acknowledgements We gratefully acknowledge Spyros Arvanitis, Heinz Hollenstein and Martin Wörter (KOF, ETHZ, Zurich) for providing the prepared panel data as well as for sharing their tacit knowledge of this dataset, the participants at the "Science and Technology Research In a Knowledge-based Economy" (STRIKE) conference in KU Leuven, Belgium October 18th-20th 2007, Jacques Mairesse, Luis Miotti, Julio Raffo, Stéphane Robin, and the participants at the "Innovation seminar" at the French Ministry of Industry, March 4th 2008. Usual disclaimers apply.

\section{References}

Arrow KJ (1962) Economic welfare and the allocation of resources for innovation. In: Richard $\mathrm{N}$ (ed) The rate and direction of inventive actvity: economic and social factors. Princeton University Press, pp 602-626

Arvanitis S (2008) Innovation and labour productivity in the Swiss manufacturing sector: an analysis on firms panel data. In: Van Beers C, Kleinknecht A, Ortt R, Verburg R (ed) Determinants of innovative behaviour: a firm's internal practices and its external environment. Palgrave Macmillan

Bernstein JI, Nadiri MI (1989) Research and development and intra-industry spillovers: an empirical application of dynamic duality. Rev Econ Stud 56(2):249-269

Belderbos R, Carree M, Lokshin B (2004) Cooperative R\&D and firm performance. Res Policy 33(10):1477-1492

Bloom N, Schankerman M, Van Reenen J (2007) Identifying technology spillovers and product market rivalry. NBER Working Paper No 13060

Cassiman B, Veugelers R (2006) In search of complementarity in innovation strategy: internal $R \& D$, cooperation in R\&D and external technology acquisition. Manag Sci 52(1):68-82

Ceccagnoli M (2005) Firm heterogeneity, imitation and the incentives for cost reducing R\&D effort. J Ind Econ 53(1):83-100

Cohen WM (1995) Empirical studies of innovative activity. In: Stoneman P (ed) Handbook of the economics of innovation and technological change. Basil Blackwell, pp 182-264

Cohen WM, Levinthal D (1989) Innovation and learning: the two faces of R\&D. Econ J 99(397):569-596

Crépon B, Duguet E, Mairesse J (1998) Research and development, innovation and productivity: an econometric analysis at the firm level. Econ Innov New Technol 7(2):115-158

Eeckhout J, Jovanovic B (2002) Knowledge spillovers and inequality. Am Econ Rev 92(5):1290_ 107

Greene W (2006) Censored data and truncated distributions. In: Mills T, Patterson K (ed) Palgrave handbook of econometrics, vol 1. Theoretical Econometrics. Palgrave-Macmillan, London, pp 695-736

Griffith R, Huergo E, Mairesse J, Peters B (2006) Innovation and productivity across four European countries. Oxf Rev Econ Policy 22(4):483-498

Jaffe A (1986) Technological opportunity and spillovers of R\&D. Am Econ Rev 76:984-1001

Kogut B, Kulatilaka N (2001) Capabilities as real options. Organ Sci 12(6):744-758

Leahy D, Neary JP (2007) Absorptive capacity, R\&D spillovers, and public policy. Int J Ind Organ 25(5):1089-1108

Levin RC (1988) Appropriability, R\&D spending, and technological performance. Am Econ Rev 78(2):424-428 
Levin RC, Klevorick AK, Nelson RR, Winter SG (1987) Appropriating the returns from industrial research and development. Brookings Pap Econ Act Econ Stud Prog, Brookings Institution 18(3):783-832

Lhuillery S, Pfister E (2009) R\&D cooperation and failures in innovation projects: empirical evidence from French CIS data. Res Policy 38(1):45-57

Link AL, Neufeld JL (1986) Innovation versus imitation: investigating alternative R\&D strategies. Appl Econ 18(12):1359-1363

Lööf H, Heshmati A (2002) Knowledge capital and performance heterogeneity: a firm-level innovation study. Int J Prod Econ 76(1):61-85

Nelson R, Winter S (1982) An evolutionary theory of economic change. Belknap, Cambridge

OECD (1992) Oslo Manual: guidelines for collecting and interpreting innovation data, 1st edn. OECD, Paris

Raffo J, Lhuillery S, Miotti L (2008) Northern and southern innovativity: a comparison across European and Latin American countries. Eur J Dev Res 20(2):219-239

Rigobon R, Stoker T (2007) Estimation with censored regressors: basic issues, special issue in honor of Daniel Mc Fadden. Int Econ Rev 48(4):1441-1467

Spence M (1984) Cost reduction, competition, and industry performance. Econometrica 52(1):101-121

Vandekerckhove J, De Bondt R (2008) Asymmetric spillovers and investments in research and development of leaders and followers. Econ Innov New Technol 17(5):417-433 